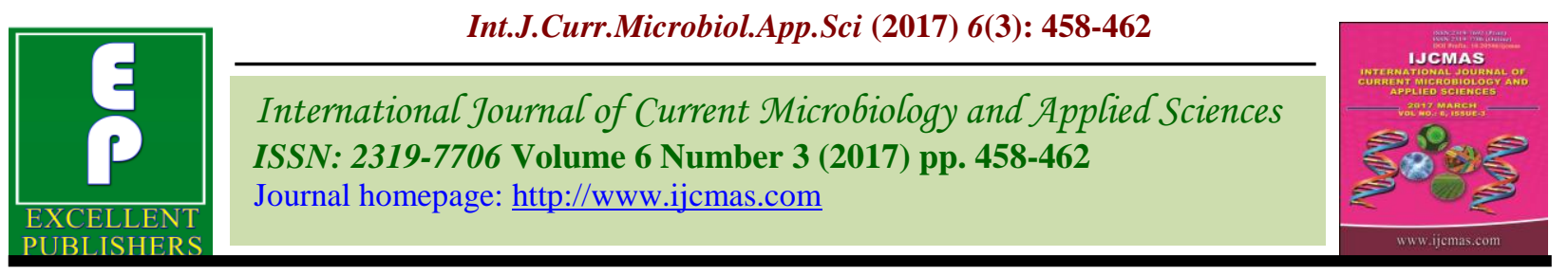

Original Research Article

https://doi.org/10.20546/ijcmas.2017.603.053

\title{
Performance of Ridge Gourd (Luffa acutangula L. Roxb.) Varieties and Nature of Cultivation for Yield and Yield Attributes
}

\author{
K. Karthick ${ }^{1}$, G.S. Patel $^{1}$, V. Shanmugapriya ${ }^{2}$ and Bhavik Aravindbhai Varsat ${ }^{1}$ \\ ${ }^{1}$ Department of Vegetable Science, College of Horticulture, S.D. Agricultural University, \\ Jagudan, Gujarat, India \\ ${ }^{2}$ Department of Agricultural Entomology, C.P. College of Agriculture, S.D. Agricultural \\ University, Sardarkrushinagar, Gujarat, India \\ *Corresponding author
}

\begin{tabular}{|c|c|}
\hline & A B S T R A $\mathbf{C}$ \\
\hline Keywords & \multirow{4}{*}{$\begin{array}{l}\text { The present experiment was conducted at Horticulture Instructional Farm, C.P. College of } \\
\text { Agriculture, S.D. Agricultural University, Gujarat. The present experiment results were } \\
\text { recorded and reported that maximum days taken for last picking, weight of fruit, number } \\
\text { of fruits per plant, yield per plant, yield per plot, yield per hectare and Benefit cost ratio as } \\
\text { well as minimum days taken for first picking in with trellising system as compared to } \\
\text { without trellising system. In case, performance of varieties for yield parameters like } \\
\text { highest weight of fruit, number of fruits per plant, yield per plant, yield per plot, yield per } \\
\text { hectare and Benefit cost ratio as well as minimum days taken for first picking were } \\
\text { recorded with variety Pusa Nasdar }\left(\mathrm{v}_{3}\right) \text {. Maximum days taken for last picking were } \\
\text { recorded with variety PKM-1 }\left(\mathrm{v}_{5}\right) \text {. }\end{array}$} \\
\hline $\begin{array}{l}\text { Trellising, Nature of } \\
\text { cultivation, } \\
\text { Varieties, } \\
\text { Kniffin, Yield. }\end{array}$ & \\
\hline Article Info & \\
\hline $\begin{array}{l}\text { Accepted: } \\
10 \text { February } 2017 \\
\text { Available Online: } \\
10 \text { March } 2017\end{array}$ & \\
\hline
\end{tabular}

\section{Introduction}

Ridge gourd belongs to genus Luffa species of cucurbitaceae family. It is rather difficult to assign accurately the indigenous areas of Luffa species. Ridge gourd is low in saturated fat and cholesterol, high in dietary fibre, vitamin $\mathrm{C}$, riboflavin, zinc, thiamin, iron, magnesium and manganese. The nutritional value of gourd makes it suitable for maintaining optimum health and weight lose. It has excellent cooling properties. Ridge gourd contains a gelatinous compound called luffein (Thamburaj and Singh, 2013).

This trailing technique mainly used for vegetables like tomato, capsicum, cucurbits and some vine crops. Trailing provides better opportunity to the crop to exploit the sunlight by production of maximum vine length, number of leaves and side branches resulting in better assimilation of carbohydrates. To increase the productivity of crop, it is essential to standardize the agro techniques such as trailing of vines with appropriate manner to improve the fruit set, fruit yield and good quality of fruits.

The main objectives of this experiment are to know the suitable ridge gourd varieties and method of cultivation for obtaining high yield in North Gujarat region. 


\section{Materials and Methods}

This present experiment was evaluated at Horticulture Instructional Farm, C.P. College of Agriculture, S.D. Agricultural University, Gujarat. This experiment was planned with two factors viz., - I-nature of cultivation (S) and II-varieties (V) with four replications under Factorial Randomized Block Design concept. Nature of cultivation factor was with two levels viz., with trellising $\left(\mathrm{s}_{1}\right)$ and without trellising $\left(\mathrm{s}_{2}\right)$ system and six varieties viz., Gujarat Anand Ridge Gourd-1 ( $\left.\mathrm{v}_{1}\right)$, Hisar Kalitori $\left(\mathrm{v}_{2}\right)$, Pusa Nasdar $\left(\mathrm{v}_{3}\right)$, Arka Sujath $\left(\mathrm{v}_{4}\right)$, PKM- $1\left(\mathrm{v}_{5}\right)$ and Local $\left(\mathrm{v}_{6}\right)$. In this experiment plants were trailed over the kniffin structure for with trellising system and plants were allowed to trail on the soil surface for without trellising system. Yield characters data were absorbed from each treatment analysed by using the principles of 'Analysis of Variance' techniques as described by Panse and Sukhatme (1978). Finally, Benefit Cost ratio were calculated for each varieties and factors and compared with other varieties and factors.

\section{Results and Discussion}

\section{Effect of nature of cultivation for yield parameters}

The analyzed data for yield parameters are presented in table 1. The Factor I nature of cultivation (S) recorded significant results for all yield. Maximum days taken for last picking (106.19), weight of fruit (277.67 g), number of fruits per plant (9.95), yield per plant $(2.81 \mathrm{~kg})$, yield per plot $(8.89 \mathrm{~kg})$ and yield per hectare $(14.82 \mathrm{t})$ as well as minimum days taken for first picking (47.49) were recorded for with trellising system $\left(\mathrm{s}_{1}\right)$. Minimum days taken for last picking (101.77), weight of fruit (257.02 g), number of fruits per plant (8.77), yield per plant (2.29 $\mathrm{kg})$, yield per plot $(7.01 \mathrm{~kg})$ and yield per hectare $(11.68 \mathrm{t})$ as well as maximum days taken for first picking (50.30) were recorded for without trellising system $\left(\mathrm{s}_{1}\right)$.

Beneficial and economical yield characters were observed from with trellising $\left(s_{1}\right)$. In kniffin system vines and leaves are do not contact with soil so that, there is less chance of disease damages from soil living fungi and bacteria. If there is no disease problem then plant can grow more duration. The leaves are fully exposed to sunlight so, photosynthesis rate will increase it could be increase the number of picking as well as yield parameters. This present investigation results were similar to Bhokare and Ranpise (2004), Joshi et al., (1995) and Bhagat (2012) in bitter gourd as well as Shinde (2014) in bottle gourd.

\section{Effect of varieties for yield parameters}

The Factor II varieties (V) recorded significant results for all yield characters. Minimum days taken for first picking (38.74) was recorded with variety Pusa Nasdar $\left(\mathrm{v}_{3}\right)$ whereas maximum days taken for last picking (117.92) was recorded for variety PKM-1 ( $\left.\mathrm{v}_{5}\right)$ which was statistically at par with variety Arka Sujath (114.82). Variety Pusa Nasdar $\left(v_{3}\right)$ showed highest weight of fruit (309.94 $\mathrm{g}$ ), number of fruits per plant (11.67), yield per plant $(3.62 \mathrm{~kg})$, yield per plot $(10.90 \mathrm{~kg})$ and yield per hectare (18.17 t) which was statistically at par with varieties Arka Sujath for weight of fruit (308.15 g) and Gujarat Anand Ridge Gourd-1 (11.23) for number of fruits per plant. The variety Local $\left(\mathrm{v}_{6}\right)$ recorded minimum weight of fruit $(183.62 \mathrm{~g})$ whereas minimum number of fruits per plant (5.74), yield per plant (1.61 kg), yield per plot $(5.48 \mathrm{~kg})$ and yield per hectare $(9.14 \mathrm{t})$ were recorded with variety PKM-1 ( $\left.\mathrm{v}_{5}\right)$. Maximum days taken for first picking (62.24) and minimum days taken for last picking (89.96) were recorded with varieties PKM-1 ( $\left.\mathrm{v}_{5}\right)$ and Gujarat Anand Ridge Gourd-1 respectively. 
Table.1 Yield parameters of ridge gourd under different nature of cultivation and different varieties

\begin{tabular}{|c|c|c|c|c|c|c|c|}
\hline Treatments & $\begin{array}{c}\text { Days } \\
\text { taken for } \\
\text { first } \\
\text { picking }\end{array}$ & $\begin{array}{c}\text { Days } \\
\text { taken } \\
\text { for last } \\
\text { picking }\end{array}$ & $\begin{array}{c}\text { Weight } \\
\text { of fruit } \\
\text { (g) }\end{array}$ & $\begin{array}{c}\text { Number } \\
\text { of fruits } \\
\text { per } \\
\text { plant }\end{array}$ & $\begin{array}{c}\text { Yield } \\
\text { per } \\
\text { plant } \\
(\mathrm{kg}) \\
\end{array}$ & $\begin{array}{c}\text { Yield } \\
\text { per plot } \\
\text { (kg) }\end{array}$ & $\begin{array}{l}\text { Yield per } \\
\text { hectare } \\
\text { (t) }\end{array}$ \\
\hline \multicolumn{8}{|c|}{ Nature of cultivation $(\mathbf{S})$} \\
\hline $\mathrm{s}_{1}$ & 47.49 & 106.19 & 277.67 & 9.95 & 2.81 & 8.89 & 14.82 \\
\hline $\mathrm{s}_{2}$ & 50.30 & 101.77 & 257.02 & 8.77 & 2.29 & 7.01 & 11.68 \\
\hline S.Em \pm & 0.71 & 1.49 & 4.57 & 0.24 & 0.07 & 0.21 & 0.35 \\
\hline C.D. at $5 \%$ & 2.04 & 4.29 & 13.15 & 0.70 & 0.19 & 0.60 & 1.00 \\
\hline \multicolumn{8}{|l|}{ Varieties (V) } \\
\hline $\mathrm{v}_{1}$ & 43.09 & 89.96 & 271.17 & 11.23 & 3.09 & 9.74 & 16.24 \\
\hline $\mathrm{v}_{2}$ & 42.69 & 102.54 & 252.49 & 9.00 & 2.27 & 6.78 & 11.30 \\
\hline $\mathrm{v}_{3}$ & 38.74 & 100.92 & 309.94 & 11.67 & 3.62 & 10.90 & 18.17 \\
\hline $\mathrm{v}_{4}$ & 57.43 & 114.82 & 308.15 & 9.67 & 2.86 & 8.88 & 14.81 \\
\hline $\mathrm{v}_{5}$ & 62.24 & 117.92 & 278.69 & 5.74 & 1.61 & 5.48 & 9.14 \\
\hline $\mathrm{v}_{6}$ & 49.17 & 97.71 & 183.62 & 8.85 & 1.85 & 5.91 & 9.84 \\
\hline S.Em \pm & 1.23 & 2.58 & 7.91 & 0.42 & 0.12 & 0.36 & 0.60 \\
\hline C.D. at $5 \%$ & 3.54 & 7.42 & 22.77 & 1.22 & 0.33 & 1.04 & 1.74 \\
\hline \multicolumn{8}{|c|}{ Interaction $(\mathbf{S x V})$} \\
\hline $\mathrm{s}_{1} \mathrm{~V}_{1}$ & 41.89 & 90.68 & 284.70 & 12.21 & 3.49 & 11.14 & 18.56 \\
\hline $\mathrm{S}_{1} \mathrm{~V}_{2}$ & 41.93 & 104.50 & 262.25 & 9.20 & 2.41 & 7.03 & 11.72 \\
\hline $\mathrm{S}_{1} \mathrm{~V}_{3}$ & 36.42 & 103.12 & 315.29 & 12.64 & 3.98 & 12.25 & 20.41 \\
\hline $\mathrm{s}_{1} \mathrm{~V}_{4}$ & 56.33 & 119.07 & 314.33 & 10.39 & 3.15 & 10.11 & 16.85 \\
\hline $\mathrm{s}_{1} \mathrm{~V}_{5}$ & 60.54 & 120.00 & 291.25 & 6.25 & 1.82 & 6.17 & 10.28 \\
\hline $\mathrm{s}_{1} \mathrm{~V}_{6}$ & 47.80 & 99.77 & 198.17 & 9.04 & 2.03 & 6.67 & 11.11 \\
\hline $\mathrm{s}_{2} \mathrm{~V}_{1}$ & 44.28 & 89.25 & 257.64 & 10.26 & 2.71 & 8.35 & 13.91 \\
\hline $\mathrm{S}_{2} \mathrm{~V}_{2}$ & 43.45 & 100.59 & 242.73 & 8.81 & 2.14 & 6.53 & 10.88 \\
\hline $\mathrm{S}_{2} \mathrm{~V}_{3}$ & 41.06 & 98.72 & 304.58 & 10.71 & 3.27 & 9.56 & 15.93 \\
\hline $\mathrm{S}_{2} \mathrm{~V}_{4}$ & 58.54 & 110.57 & 301.97 & 8.95 & 2.58 & 7.66 & 12.76 \\
\hline $\mathrm{S}_{2} \mathrm{~V}_{5}$ & 63.94 & 115.84 & 266.15 & 5.23 & 1.39 & 4.80 & 8.00 \\
\hline $\mathrm{s}_{2} \mathrm{~V}_{6}$ & 50.55 & 95.65 & 169.06 & 8.65 & 1.67 & 5.15 & 8.58 \\
\hline S.Em \pm & 1.74 & 3.65 & 11.18 & 0.59 & 0.16 & 0.51 & 0.85 \\
\hline C.D. at $5 \%$ & NS & NS & NS & NS & NS & NS & NS \\
\hline C. V.\% & 7.11 & 7.01 & 8.37 & 12.79 & 12.86 & 12.90 & 12.90 \\
\hline
\end{tabular}


Table. 2 Economics and benefit cost ratio for different nature of cultivation and different varieties

\begin{tabular}{|c|c|c|c|c|c|}
\hline Treatments & $\begin{array}{c}\text { Yield/ha } \\
\text { (t) }\end{array}$ & $\begin{array}{c}\text { Gross } \\
\text { returns } \\
\left.\left(\Sigma^{=}\right) / \mathbf{h a}\right)\end{array}$ & $\begin{array}{l}\text { Total cost of } \\
\text { cultivation } \\
\left.\left(\Sigma^{\prime}\right) / h a\right)\end{array}$ & $\begin{array}{c}\text { Net } \\
\text { returns } \\
\left.\left(\Sigma^{F}\right) / \mathbf{h a}\right)\end{array}$ & $\begin{array}{l}\text { Benefit: } \\
\text { Cost ratio }\end{array}$ \\
\hline \multicolumn{6}{|c|}{ Nature of Cultivation (S) } \\
\hline $\mathrm{s}_{1}$ & 14.82 & 296431 & 64951 & 231480 & 4.6 \\
\hline $\mathrm{S}_{2}$ & 11.68 & 233528 & 55452 & 178076 & 4.2 \\
\hline \multicolumn{6}{|l|}{ Varieties (V) } \\
\hline $\mathrm{v}_{1}$ & 16.24 & 324708 & 60718 & 263990 & 5.3 \\
\hline $\mathrm{v}_{2}$ & 11.30 & 226042 & 60518 & 165524 & 3.7 \\
\hline $\mathrm{v}_{3}$ & 18.17 & 363375 & 60918 & 302457 & 6.0 \\
\hline $\mathrm{V}_{4}$ & 14.81 & 296125 & 60318 & 235807 & 4.9 \\
\hline $\mathrm{v}_{5}$ & 9.14 & 182792 & 59718 & 123074 & 3.1 \\
\hline $\mathrm{v}_{6}$ & 9.84 & 196833 & 59018 & 137815 & 3.3 \\
\hline
\end{tabular}

Varietal evaluation and screening of variety is very important necessary process to obtain most suitable and economical variety for farmer's cultivation. Each variety having its own specific genetical characters which are inherent. The variation in yield parameters for different varieties due to its genetic behaviours. This present investigation results are similar to Lingaiah et al., (1993) and Jaiswal et al., (1995) in bitter gourd, Ahmed et al., (2004) in cucumber, Kutty and Dharmtti (2005), Narayan et al., (2006), Raja et al., (2007) and Nalawade et al., (2011) in bitter gourd, More (2012) in water melon, Haque et al., (2014) in snake gourd as well as Jamal Uddin et al., (2014) in bottle gourd.

\section{Effect of nature of cultivation and varieties for economics}

Results regarding in economics i.e., gross return, total cost of cultivation, net return and Benefit : Cost ratio are presented in table 2. The sale price of ridge gourd was ₹ 20 per $\mathrm{Kg}$. The results indicated that with trellising system of ridge gourd c ultivation recorded maximum gross return ( $₹ 2,96,431)$, net return $(₹ 2,31,480)$ and Benefit : Cost ratio (4.6) than without trellising system of cultivation. Because, with trellising system recorded highest for all yield parameters. In case of varieties variety Pusa Nasdar recorded maximum gross return ( $₹ 3,63,375)$, net return $(₹ 3,02,457)$ and Benefit : Cost ratio (6.0) than other varieties. Because, the variety Pusa Nasdar recorded highest for yield per plant, plot and hectare. These findings were similar to Bhagat (2012) in bitter gourd and Shinde (2014) in bottle gourd. From the results of field experiment, this study concludes that growing ridge gourd variety Pusa Nasdar and trailing the vines on kniffin structure (with trellising) is beneficial and economical for the farmers of North Gujarat region.

Highlights: The variety Pusa Nasdar and with trellising system of cultivation method suitable for highest yield and Benefit Cost ratio.

\section{Acknowledgement}

The authors are highly thankful to the College of Horticulture, S.D. Agricultural University, Jagudan for providing necessary facilities support to carry out this research work.

\section{References}

Ahmed, M., Hamid, A. and Akbar, Z. 2004. Growth and yield performance of six cucumber (Cucumis sativus L.) cultivars 
under agro-climatic conditions ofRawalakot, Azad Jammu and Kashmir. Int. J. Agri. Biol., 6(2): 1560-8530.

Bhagat Dattu Laxman. 2012. Performance of Bitter gourd (Momordicacharantia L.) varieties and nature of cultivation with respect to growth, yield and quality.M.Sc (Hort.) Thesis (Unpublished). S.D. Agricultural University, Sardar krushinagar.

Bhokare, S.S. and Ranpise, S.A. 2004. Effect of different training systems on incidence of pest, diseases and yield of bitter gourd (Momordicacharantia L.) cv. Konkan Tara under Konkan conditions of Maharashtra. Haryana J. Horticultural Sci., 33(1/2): 139-141.

Haque, M.M., Uddin, M.S., Mehraj, H. and Jamal Uddin, A.F.M. 2014. Evaluation of snake gourd (trichasanthesanguina) test hybrids comparing with four popular checks. Int. J. Appl. Sci. Biotechnol., 2(4): 525-528.

Jaiswal, J.P., Subedi, P.P. and Bhattaraj, S.P. 1995. Outreach research report on cucurbits crops for off season production. Vegetable Sci., 17(2): 186-190.

Jamal Uddin, A.F.M., Tahidul, M.I., Chowdhury, M.S.N., Shiam, I.H. and Mehraj, H. 2014. Evaluation of bottle gourd (lagenariasiceraria) to growth and yield. Int. J. Biosci., 5(12): 7-11.

Joshi, V.R. 1995. Effects of training systems and planting seasons on yield of bitter gourd. J. Maharashtra Agri. Univ., 22(2): 267269.

Kutty, M.S. and Dharmatti, P.R. 2005. Correlation and path coefficient studies in bittergourd (Momordicacharantia L.) Karnataka J. Horticulture, 1(3): 7-11.

Lingaiah, H.B., Uthaiah, B.C. and Herle, P.S. 1993. Performance of bitter gourd cultivars in coastal Karnataka. Curr. Res.
University of Agri. Sci., (Bangalore), 22(1): 16.

More Sandeep Gangadhar. 2012. Performance of different varieties with respect to plant growth, flowering, sex expression, yield and quality of watermelon (citrulluslanatusThumb Mansf) under north Gujarat climatic condition. M.Sc (Hort.) Thesis (Unpublished). S.D. Agricultural University, Sardarkrushinagar.

Nalawade, N.P., Chavan, S.D., Barkule, S.R., Bhosale, A.M. and Shinde, S.J. 2011. Varietal performance of bitter gourd (Momordicacharantia L.) in respect of growth and yield under Parbhani conditions, Maharastra. Int. J. Plant Sci., (Muzaffarnagar) 6(1): 80-82.

Narayan, R., Ahmed, N. and Shahnaz, M. 2006. Evaluation of some bittergourd genotypes for yield traits and genetic parameters under Kashmir conditions. Environ. Ecol., 24(3): 750-752.

Panse, V.G. and Sukhatme, P.V. 1978. Statistical Methods for Agricultural Workers, Indian Council of Agriculture Research Publication, New Delhi pp.369.

Raja, S., Bagle, B.G. and Dhandar, D.G. 2007. Genetic variability studies in bittergourd for zero irrigated condition of semi-arid ecosystem. Indian J. Horticulture, 64(4): 425-429.

Shinde Ramchandra Diliprao. 2014. Effect of nature of cultivation on different varieties of bottle gourd (Lagenbariasiceraria (Mol.) standl.).M.Sc (Hort.) Thesis. (Unpublished) S.D. Agricultural University, Sardarkrushinagar.

Thamburaj, S. and Singh, N. 2013. Text book of Vegetables, Tubercrops and Spices, Indian Council of Agriculture Research Publications, New Delhi, p. 309.

\section{How to cite this article:}

Karthick, K., G.S. Patel, V. Shanmugapriya and Bhavik Aravindbhai Varsat . 2017. Performance of Ridge Gourd (Luffa acutangula 1. Roxb.) Varieties and Nature of Cultivation for Yield and Yield Attributes. Int.J.Curr.Microbiol.App.Sci. 6(3): 458-462. doi: https://doi.org/10.20546/ijcmas.2017.603.053 